\title{
IMPLEMENTATION OF PEDAGOGICAL ACTIVITY OF LABOUR PROTECTION SPECIALISTS IN WORK ENVIRONMENT
}

\author{
Dace Brizga \\ Latvia University of Agriculture
}

\begin{abstract}
Human health and wellness are significantly affected by the observance of labour and civil protection rules both in the work environment and in social life. They are also affected by adequate training which is organised according to the age group and situation in order to reduce the formal attitude to the observance of all types of safety rules. Labour protection specialists themselves will be those who will respect and ensure the observance of the labour and civil protection rules. The aim of this study was to research the implementation of pedagogical activities of labour safety specialists in the work environment. The methodologies used in the research were semi-structured interviews, questionnaires and the analysis of the qualitative data and comments, submitted by labour protection specialists electronically, to clarify the implementation of pedagogical activities in the context of the UNESCO concept of sustainable development of education with the aim to reduce formal attitude towards the observance of labour and civil protection rules, using the model of ecological approach - Process-Person-Context-Time. The text analysis was carried out using the software programme Weft QDA. By improving labour protection specialists' pedagogical competence, the staff's (employers', employees') expertise also improves or partially improves.
\end{abstract}

Keywords: competence, learning, labour protection specialist.

\section{Introduction}

Human health and wellness are significantly affected by the observance of labour and civil protection rules both in the work environment and in social life. They are also affected by adequate training which is organised according to the age group and situation in order to reduce the formal attitude to the observance of all types of safety rules.

The competence of labour protection specialists (LP programme students adults having master's or bachelor's degree in some other sector of the economy) is influenced by being present in different environments, since the environment is physical, social, spiritual and informative surroundings where these specific environmental aspects are in constant interaction. In these relationships the physical environment is the one made by nature or humans and it is characterised by physical conditions and total amount of spatial objects; social environment - the social environment of an individual's life, relationships 
between people, their material and spiritual values; informative environment the total amount of resources and processes which demonstrate the knowledge accumulated and applied by each individual society (Ansone et al., 1999); work environment - the workplace with its physical, chemical, psychological, biological, physiological and other factors which an employee is exposed to when performing the work (Labour Protection Law, 2002), family environment - In the narrow sense of its definition, a family consists of the spouses and their children while they are still part of a common household (Civil Law, 1992, 214). Ecological approach to labour protection specialists ensures the implementation of pedagogical competence in the development of the learning environment of the personnel - organising and conducting classes, managing and ensuring high quality teaching to minimise the opportunities of the formation of a formal attitude. Learning environment includes the physical (place, furniture, lighting, air quality, IT devices, etc.), social (the instructor/teacher, audience) and informative (programmes, instructions, documents, study materials, etc.) environment.

During the practice period in pedagogy and work psychology it is advisable to minimise the formal attitude to the LP and CP (labour and civil protection) and ensure the personnel's (both employers' and employees') wellness (Brizga \& Peks, 2014) in the work environment, in order to minimise the number of traumatism and occupational diseases. The personnel's learning and study influence on the development of attitude and development can be evaluated basing on the PPCT system: Process-Person-Context-Time (Bronfenbrenner, 1976, 1977, Brofenbrenner \& Evans, 2000, Brofenbrenner, 2005, Brofenbrenner \& Morris, 2006), where the most significant are the process, the person and also the context - the formal, informal and non-formal learning environment. Both the process and the context should promote the affective, behavioural and cognitive component of attitude, as well as the development of the function of attitude (heuristic, schematic, attitude as a process), as mentioned in the research conducted earlier (Brizga et al., 2013).

Positive attitude affects the personnel's/individual's results, their improvement with contributions to the study process (in the development and improvement of the work/study environment, in improvement of the quality of instructions and regulations, in the selection of appropriate teaching methods). Pedagogical environment and situations should provide free, creative, effective and purposeful education (Briede \& Peks, 1998), but the teacher who is the labour protection specialist in the work environment should not manage but direct education, providing a sufficiently wide scope of aims as well as the possibilities of choices of aims and the ways to achieve them. By evaluating one's own and other people's experience, it is important to change one's attitude and with the correct behaviour influence public behaviour both in the work 
environment and in family, since in the UNESCO document, which is related to the platform of environmental education, it has been pointed out that it is necessary to integrate the value-based sustainable development into all study aspects, enabling each individual to assess critically oneself and the society, assuming the responsibility for the development of a sustainable future (ESD Competences UNECE, 2012). Experiential learning is the process of learning through experience, acquiring new experience from the viewpoints of different people and testing this experience in practice - evaluating the existing practice and values. In the process of learning each member of the group is actively involved in sharing his/her positive or negative experience and reflection knowledge reconstruction takes place (Colin, 2010). Reflective practices show what people really do (Ghaye, 2011) and feedback (positive reviews) helps evaluate and make a bigger effort in changing the existing situation, because: "When trying to improve work and working lives through reflection (of one kind or another), thinking and conversations often get stuck with vocabularies of human deficit, and in so doing fail to unlock the creative potential of those involved" (Ghaye, 2011, 9). In the study process the labour protection specialist has to be able to perceive the learner as an equal partner to develop self reflection and within the framework of "action learning" there is a strong focus on "learning with others and from others" in a learning set, (Hale, 2013), since learning improves the emotional intelligence and those who have learnt to change their way of thinking, attitude and opinions can influence the culture of the organisation and the personnel's attitude in the problem solving processes (Kramer, 2007), emphasizing the fact that the methodology of "action learning" was first designed by Reg Revans in England more than 60 years ago.

On the basis of the ecological approach to education, "pedagogical competence of labour protection specialists forms in a mesosystem, consisting of two microsystems, i.e. work and education, and it develops in formal and non-formal education as well as during informal learning" (Bertaitis, 2013, 81). The researcher points out that labour protection specialists' insufficient pedagogical competence in many cases is an indirect cause of accidents, since the necessity for the pedagogical competence was updated only in 2011 when the labour protection specialist's Profession standard was published.

The education trend of the 21st century is towards Education for Sustainable Development (ESD) with the aim of creating a peaceful and sustainable society in which people are able to realize themselves fully in the economy and society as a whole, where they are able to understand the local problems and see them in a global context. The ESD includes five learning types or pillars „Learning to know", "Learning to be", "Learning to live together", "Learning to do", "Learning to transform oneself and society" (UNESCO, 2011). The fifth pillar "Learning to transform oneself and society"- to develop 
abilities and desire to integrate the sustainable life style in oneself and in the society - is one of the questions to which answers should be found in order to change the formal attitude towards labour and civil protection prevailing in society.

The aim of this study was to research the implementation of pedagogical activities of labour safety specialists in the work environment.

The methodologies used in the research were semi-structured interviews, questionnaires and the analysis of the qualitative data and comments (submitted by email) by work safety specialists to clarify the implementation of pedagogical activities in the context of UNESCO concept of education for sustainable development with the aim to reduce formal attitude towards the observance of labour and civil protection rules, using the model of the ecological approach - Process-Person-Context-Time.

\section{Materials and methods}

Both labour protection specialists and the personnel (respondents - within the context of research) employed in different sectors of the economy are adults who "learn to think for themselves rather than act upon the assimilated beliefs, values, feelings and judgements of others" (Mezirow, 2003, 1). That is the way transformative learning may be understood. Learning to decide more insightfully for oneself what is right, good and beautiful is centrally concerned with bringing into awareness and negotiating one's own purposes and values. The learning was organised basing on J. Mezirow's transformative learning theory which is based on solving adult problem situations, basing on the existing positive or negative experience, system of values, evaluating them reflectively in a dialogue with oneself or with others, the attitude changes (Taylor, 2007, 2008). The main elements of transformative learning which were initially studied are: individual experiences, critical reflection and dialogue (Taylor, 1998). Carrying out further research, the scientist concludes that holistic orientation, awareness of context and authentic practice are closely related to the previously mentioned elements. The theory is based on the goal oriented changes which develop into two directions - individual growth (evaluation of personal attitude), social and individual growth combined holistically (Mezirow, Taylor 2009). Applying this theory, the specialists who acquire labour and civil protection, basing on the existing experience, form a dialogue and carry out self-evaluation during the learning process, using images, videos, emergency situation analysis, assessment, etc.

To clarify the implementation of pedagogical activity of labour protection specialists in the work environment, using the model of ecological approach Process-Person-Context-Time, in the beginning, the author of the research 
carried out unstructured discussions with labour protection specialists. The aim of these discussions was to clarify how to promote the changes of the personnel's /employees' competences in order to change their formal attitude towards the observance of labour and civil protection regulations. Sixteen labour protection specialists from different enterprises and organisations were involved in the research. Questionnaires and discussions were used in the surveys. The qualitative data and comments obtained in the survey were then/later electronically submitted by the labour protection specialists to the author of the research. Afterwards, the criteria for assessing changes in the attitudes were prepared.

The author of the research then summarised and analysed the submitted data using Content analysis, applying a free qualitative analysis software application Weft QDA. After getting acquainted with the data required for the research and studying theoretical literature, the following categories were formulated:

$\begin{array}{ll}\text { Codes } & \text { Codes of Categories } \\ \text { improved } & \begin{array}{l}\text { The attitude towards labour and civil protection } \\ \text { improved. }\end{array} \\ \text { partly improved } & \begin{array}{l}\text { The attitude towards labour and civil protection } \\ \text { partly improved. } \\ \text { The attitude towards labour and civil protection } \\ \text { did not change }\end{array} \\ & \text { did not change. }\end{array}$

In order to ensure anonymity, the names of different enterprises and organisations of the sectors of the economy, where the survey was carried out, were coded with numbers (Table 1).

\section{Results and discussion}

In previous research (Brizga \& Peks, 2015, 2014, Brizga et al., 2015) it was found that on the whole in society (both in the work environment and outside it, from early childhood) a formal attitude is observed towards labour and civil protection. It has been formed throughout the years and there are several reasons for that. One of these is the opinion - nothing bad will happen to me. People consider that health and life are the most important values, but due to the fast pace of life they forget about it in their everyday routines. Another reason - the interdependence of people's improper behaviour in terms of safety and people's low self esteem which is formed when a working individual is not considered as a value. 
Table 1 Opinion about the attitude towards labour and civil protection

\begin{tabular}{|c|c|c|c|c|}
\hline Enterprises/organisations & \multicolumn{2}{|c|}{$\begin{array}{c}\text { Number of } \\
\text { respondents }\end{array}$} & \multicolumn{3}{|c|}{ Attitude towards LP and CP } \\
\cline { 3 - 5 } & & Improved & $\begin{array}{c}\text { Partly } \\
\text { improved }\end{array}$ & $\begin{array}{c}\text { Did not } \\
\text { change }\end{array}$ \\
\hline 1 & & & 0 & $64^{*}$ \\
\hline 2 & 39 & 37 & 1 & 1 \\
\hline 3 & 69 & 27 & 35 & 7 \\
\hline 4 & 10 & 10 & 0 & 0 \\
\hline 5 & 13 & 2 & 10 & 1 \\
\hline 6 & 15 & 0 & 9 & 6 \\
\hline 7 & 207 & 0 & 36 & 171 \\
\hline 8 & 59 & 15 & 24 & 20 \\
\hline 9 & 22 & 12 & 0 & 10 \\
\hline 10 & 31 & 0 & 27 & 4 \\
\hline 11 & 23 & 18 & 0 & 5 \\
\hline 12 & 86 & 3 & 29 & 54 \\
\hline 13 & 207 & 36 & 0 & 171 \\
\hline 14 & 0 & 0 & 0 & 0 \\
\hline 15 & 23 & 10 & 8 & 5 \\
\hline 16 & 91 & 0 & 64 & 27 \\
\hline Total & 962 & 173 & 243 & 546 \\
\hline
\end{tabular}

* An accident (fire) happened in the undertaking and therefore the personnel had a good attitude towards the observance of labour and civil protection regulatory enactments.

One of the ways to minimise the development of formal attitude toward civil and labour protection is life skills education, emphasizing social learning and learning to transform oneself and society (Brizga et al., 2015). To live under healthy conditions an individual in an appropriate social and cultural context needs to reach a balance between free time, the time dedicated to work and activities not related to work. The French researcher Daniellou (Daniellou, 2006) developed the "Health and work transversal process" model, where he emphasized the required science knowledge levels for planning human factor and work environment assessment: the biological level comprises the knowledge of anatomy, physiology, biomechanics, biochemistry and toxicology; the cognitive level includes the knowledge about the physiological system and functions of the entire body to optimise the consumption of energy; at the psychological level the regularities and conformities of people's behaviour and activities, attitude, capabilities and mental load are assessed. The social level addresses each individual's and social group's cultural values and habits.

Having acquired the knowledge, skills and competences at all levels of the study programme "Labour protection and safety", the labour protection specialists implemented the acquired competence into practice in the enterprises 
and organisations. The labour protection specialists realized their intention - to minimize the formal attitude towards labour and civil protection which prevails in society and also to improve pedagogical competence. The results of the research (Table 1) show that the attitude towards LP and CP has improved or partly improved at least in half of the enterprises' and organisations' personnel (respondents) - 416, whereas it has not changed in 546 respondents. The differences are obviously not statistically significant. That was also approved by the hi square test $-\mathrm{p}=0.00$ (Preacher, 2001).

The answers submitted show that an accident or a problem caused by fire in an enterprise/organisation can influence the development of an adequate attitude.

Within the framework of the research the labour protection specialists pointed out the criteria which indicated the changes in attitude:

1. Drawing the employees' interest with visually observed objects pictures, video and the object itself (e.g. "ladder" in building) turned out to be successful.

2. Minimising formal attitude towards LP and CP (the manager has perceived the importance of psycho emotional risks (e.g., - for social pedagogy specialists). Work in a team (civil servants + employees) joint fire safety training in evacuating children. Cooperation has been achieved between the management and employees.

3. With regard to lifting heavy objects, the employees now are more concerned about the ways to move them and if possible they ask their colleagues to help them - something that has not been typical before. More often auxiliary devices are used. Women more often ask men for helping them lift heavy objects - something what they used to do themselves. The employees start to perceive themselves as a value and part of an undertaking. From the discussions with the employees it can be concluded that there is a desire to think about themselves, their health and create a good and safe environment to work in. The contact between the employees and employers has improved. The employees are happy to come to work. They have the feeling that they are needed because their views are listened to and respected. The employers feel the employees' positive attitude and the problem issues solved by joint efforts lead to positive results which manifest themselves in the amount of work and final result.

4. The number of accidents has decreased.

5. The use of presentations (photos, videos) in the process of teaching improved the understanding about work safety issues (the employees have a deeper understanding of practical training). From the discussions during the training process it was concluded that the study 
programme should be specified, by including the employees' recommendations.

6. The employees' behaviour changed. After the studies, when the survey was carried out it was observed that the employees wanted to find out the correct answers to those questions which were not clear to them, so they had common issues to discuss. Thus the interest arose regarding LP issues. When the discussions started, those who had not sent the questionnaires felt uncomfortable and they did not seem to fit in, therefore they tried to read the questions and understand what the discussion was about.

7. A greater financial support was obtained from the management to improve the situation in labour protection. The employees had become more active in solving the issues concerning the improvement of labour productivity.

8. The employees' satisfaction with work conditions improved, when certain equipment was replaced (the organisation purchased ergonomics inventory).

9. By improving the quality of instructions it was possible to inform the employees about topical issues and those which were not included in instructions (e.g. a common gathering place in a situation when there is an emergency situation - an accident, fire, etc.).

10. Engaging in discussions, interest about safe work environment, new work techniques which could be achieved by creating an informal atmosphere (arranging a study premises) during training, the possibility for the group members to share their experience.

11. The employees themselves started to express suggestions with regard to work safety.

12. The use of individual protection aids has increased.

13. To reduce burnout syndrome among teachers, a psychologist was hired.

Some data obtained from the labour protection specialists indicate that a partial interest of employees was observed, since the employees failed to show awareness of the topicality and significance of a particular issue. Presumably the employees' lack of interest can be explained by the small number of accidents in an undertaking.

\section{Conclusion}

Evaluating the implementation of pedagogical activities of work safety specialists in the work environment and basing on the studies of the relevant 
publications and the results of content analysis of the respondents' practice reports, it was found that:

- by improving labour protection specialists' pedagogical competence, the personnel's (employers', employees') competence also improves or partly improves);

- by improving the instructions, instructing and study process, it is possible to influence the formation of a positive attitude;

- further studies on the causes of non-observance of labour protection regulations are especially topical. It is necessary to evaluate the possibilities of improving the development of labour protection specialists' pedagogical competence in educational and work environment as well as outside them in the context of the UNESCO concept of education for sustainable development.

\section{References}

Ansone, I., Kuhare, G., \& Putriņa, G. (1999). Vides zin̄̄bu terminu skaidrojošā vārdnīca. Environmental sciences thesaurus. Rīga, Jumava.

Bertaitis, I. (2013). Darba aizsardzības speciālista pedagogiskā kompetence. Pedagogical competence of the labour protection specialists. Promocijas darba kopsavilkums. Retrieved from http://llufb.llu.lv/dissertation-summary/education/ImantsBertaitis_ kopsavilkums_2013_LLU_TF_IMI.pdf

Briede, B., \& Peks, L. (1998). Pedagoğiskā vide. Pedagogical environment. Zinātniskās konferences raksti: Mājturības pedagogisiskās aktualitātes. Jelgava, LLU, 87-92.

Brizga, D., Ozolina, V., \& Peks, L. (2014). Development of specialists' attitude to occupational health and safety. Retrieved from http://tf.llu.lv/conference/ proceedings2014/Papers/88_Brizga_D.pdf.

Brizga, D., Ozolina, V., \& Peks, L. (2015). Psychological aspects of non-observance of work and civil safety regulations. Proceedings of the 8th international scientific conference Rural Environment. Education. Personality. Latvia University of Agriculture, 363-37. Retrieved from http://llufb.llu.lv/conference/REEP/2015/Latvia-Univ-Agricult-REEP2015proceedings-363-370.pdf

Brizga, D., \& Peks, L. (2014). Psychological aspects of non-observance of work safety regulations. Proceedings of the International Scientifical Conference Society, Integration, Education. 23th-24th, 2014. Retrieved from http://journals.ru.lv/ index.php/SIE

Brizga, D., \& Peks, L. (2014). Workplace wellness and specialists' attitude to work safety. International Scientific Conference. Proceedings No 7 of the 7th international scientific conference Rural Environment. Education. Personality. Latvia University of Agriculture, 90.-96. Retrieved from http://llufb.llu.lv/conference/REEP/2014/LatviaUniv-Agricult-REEP-2014proceedings-90-96.pdf

Brizga, D., \& Peks, L. (2015). Work environment assessment in the aspect of work psychology processes. 14th International Scientific Conference Engineering for Rural Development. Jelgava, 699-704. Retrieved from http://tf.llu.lv/conference/ proceedings2015/Papers/113_Brizga.pdf 
Brizga, D., Peks, L., \& Bertaitis, I. (2013). Computer use impact on students' health in the context of ecological approach to occupational safety. 12th International scientific conference „Engineering for rural development”: proceedings, Jelgava, Latvia, May 23 - 24, 2013, Latvia, University of Agriculture, 598-602. Retrieved from http://tf.llu.lv/conference/proceedings2013/Papers/111_Brizga_D.pdf

Bronfenbrenner, U. (1976). Toward an Experimental Ecology of Education. Retrieved from http://edr.sagepub.com/content/5/9/5.full.pdf

Bronfenbrenner, U. (1977). The Experimental Ecology of human development. Retrieved from http://cac.dept.uncg.edu/hdf/facultystaff/Tudge/Bronfenbrenner\%201977.pdf

Bronfenbrenner, U. (1994). Ecological models of human development. Retrieved from http://www.psy.cmu.edu/ siegler/35bronfebrenner94.pdf

Bronfenbrenner, U. (2005). Making human beings human: bioecological perspectives on human development. Sage, Thousand Oaks, 3-15

Bronfenbrenner, U., \& Evans, G. W. (2000). Developmental science in the 21st century: Emerging questions, theoretical models, research designs and empirical findings. Social Development, 9 (1), 115-125.

Bronfenbrenner, U., \& Morris, P. A. (2006). The bioecological model of human development. In W. Damon, R. M. Lerner (Eds.), Handbook of child psychology, Vol. 1: Theoretical models of human development. New York: John Wiley, 793-828.

Civil Law. (1992). Retrieved from http://likumi.lv/ta/id/225418-civillikums

Colin, B. (2010). The Experiential Learning Toolkit: Blending Practice with Concepts. London, Kogan Press.

Daniellou, F. (2006). Epistemological issues about ergonomics and human factors. In Karwowski W. (Ed). International Encyclopedia of Ergonomics and Human Factors, FL: CRC Press, 43-47.

ESD Competences UNECE. (2012). Learning for the future. Competences in Education for Sustainable Development. Retrieved from http://www.unece.org/fileadmin/DAM/ env/esd/ESD_Publications/Competences_Publication.pdf

Ghaye, T. (2011). Teaching and learning through reflective practice: A practical guide for positive action. This edition published in the Taylor \& Francis e-Library.

Hale, R. I. (2013). The leadership crisis - can Action Learning Questions provide any answers? Action Learning: Research and Practice Volume 10, Issue 2.

Kramer, R. (2007). How Might Action Learning Be Used to Develop the Emotional Intelligence and Leadership Capacity of Public Administrators? Journal of Public Affairs Education, 13 (2), 205-230

Labour Protection Law. (2002). Retrieved from http://likumi.lv/doc.php?id=26020

Mezirow, J. (2003). Epistemology of Transformative Learning. Retrieved from http://184.182.233.150/rid=1LW06CB3L-1R1W965-1Z5Z/Copy\%20of\%20Mezirow_ EpistemologyTLC.pdf

Mezirow, J., \& Taylor, E. W. (2009). Transformative Learning in Practice: Insights from Community, Workplace, and Higher Education. Retrieved from https://books.google.lv/

Preacher, K. J. (2001). Calculation for the chi-square test: An interactive calculation tool for chi-square tests of goodness of fit and independence. Retrieved from http://www.quantpsy.org/chisq/chisq.htm

Taylor, E. W. (1998). The Theory and Practice of Transformative Learning: A Critical Review. Information Series No. 374. 
Proceedings of the International Scientific Conference. Volume IV, May $27^{\text {th }}-28^{\text {th }}$, 2016. 24-34

Taylor, E. W. (2007). An update of transformative learning theory: A critical review of the empirical research (1999-2005). International Journal of Lifelong Education, 26, 173191.

Taylor, E. W. (2008). Transformative learning theory. In S. B. Merriam (Ed.), An update of adult learning: New Directions for Adult and Continuing Education, No. 119 (pp. 515). San Francisco: Jossey-Bass.

UNESCO. (2011). Education for Sustainable Development (ESD). Retrieved from http://portal.unesco.org/geography/en/ev.php-URL_ID=14132\&URL_DO=DO_ TOPIC\&URL_SECTION=201.html

Weft QDA. Retrieved from http://www.pressure.to/qda/ 